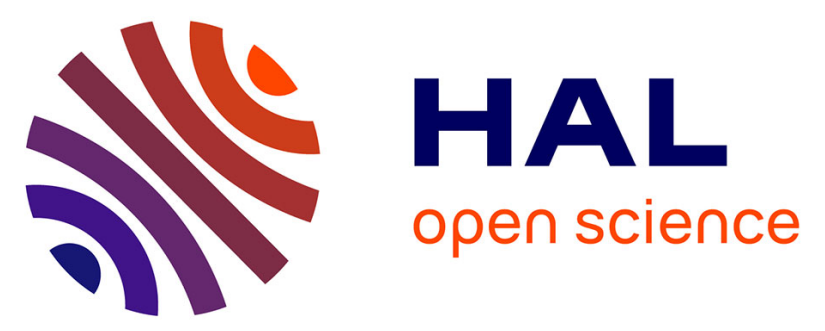

\title{
Cholinesterase activities as potential biomarkers: characterization in two freshwater snails, Potamopyrgus antipodarum (Mollusca, Hydrobiidae, Smith 1889) and Valvata piscinalis (Mollusca, Valvatidae, Müller 1774)
}

B. Gagnaire, Olivier Geffard, B. Xuereb, C. Margoum, J. Garric

\section{To cite this version:}

B. Gagnaire, Olivier Geffard, B. Xuereb, C. Margoum, J. Garric. Cholinesterase activities as potential biomarkers: characterization in two freshwater snails, Potamopyrgus antipodarum (Mollusca, Hydrobiidae, Smith 1889) and Valvata piscinalis (Mollusca, Valvatidae, Müller 1774). Chemosphere, 2008, 71 (3), p. 553 - p. 560. 10.1016/j.chemosphere.2007.09.048. hal-00453841

\author{
HAL Id: hal-00453841 \\ https://hal.science/hal-00453841
}

Submitted on 5 Feb 2010

HAL is a multi-disciplinary open access archive for the deposit and dissemination of scientific research documents, whether they are published or not. The documents may come from teaching and research institutions in France or abroad, or from public or private research centers.
L'archive ouverte pluridisciplinaire HAL, est destinée au dépôt et à la diffusion de documents scientifiques de niveau recherche, publiés ou non, émanant des établissements d'enseignement et de recherche français ou étrangers, des laboratoires publics ou privés. 
Cholinesterase activities as potential biomarkers : characterization in two freshwater snails, Potamopyrgus antipodarum (Mollusca, Hydrobiidae, Smith 1889) and Valvata

Authors

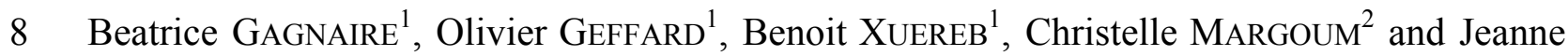
9 GARRIC $^{1 *}$

Affiliations

12

${ }^{1}$ Cemagref, Unité Biologie des Ecosystèmes Aquatiques, Laboratoire d'Ecotoxicologie, 3 bis quai Chauveau, CP 220, 69336 Lyon Cedex 09, France

$14{ }^{2}$ Cemagref, Unité Qualité des Eaux et Prévention des Pollutions, Laboratoire des 15 Micropolluants Organiques, 3 bis quai Chauveau, CP 220, 69336 Lyon Cedex 09, France

\footnotetext{
* Corresponding author: J. GARRIC, CemagreF, Lyon, France ; Tel: +33 4-72-20-89-05, Fax: +33 4-78-47-78-75, garric@1yon.cemagref.fr
} 


\section{Abstract}

Anticholinesterase insecticides constitute a major portion of modern synthetic pesticides and the assessment of cholinesterase $(\mathrm{ChE})$ inhibition is widely used as a specific biomarker for evaluating the exposure of non-target organisms to these pollutants. However, most studies on this biomarker were developed on vertebrates and among invertebrates, gastropod mollusks are rarely used. However, gastropods are important members of aquatic habitats and therefore present a high ecological relevance for freshwater ecosystems. In this context, ChE activities were characterized in two freshwater gastropod mollusks, Potamopyrgus antipodarum and Valvata piscinalis, in order to ascertain their value as sentinel species. Firstly, characterization of ChE activities was performed using different substrates (acetylcholine iodide, butyrylcholine iodide and propionylcholine iodide) and specific inhibitors (eserine, isoOMPA and BW284c51). Secondly, in vivo effect of a widely used organophosphate insecticide, chlorpyrifos, was tested on ChE activity in both species. Results suggested that $P$. antipodarum possesses two isoforms of cholinesterases, one isoform which properties are intermediate between an acetyl and a propionyl $\mathrm{ChE}$, and one minor isoform which correspond to a butyryl $\mathrm{ChE}$, while $V$. piscinalis seems to possess only one isoform which displays typical properties of an acetyl ChE. Chlorpyrifos induced no effect on $V$. piscinalis ChE. In contrast, P. antipodarum activity was significantly decreased by environmental realistic chlorpyrifos concentrations (2.86 and $14.2 \mathrm{nM})$ after seven days of contact. The present study suggests that $P$. antipodarum may be employed as a biological indicator for assessing pesticide contamination.

\section{Keywords}

Cholinesterase activity; substrates; Potamopyrgus antipodarum; Valvata piscinalis; chlorpyrifos; biomarker. 


\section{Introduction}

The measurement of the exposure to pollution and of the biological effects of toxicants has become of major importance for the assessment of the quality of the environment (van der Oost et al., 2003). The use of biological markers at the molecular or cellular level have been proposed as sensitive 'early warning' tools for biological effect measurement (van der Oost et al., 2003). This approach has been widely used both in vivo and in vitro for the evaluation of xenobiotic effects on animals (Binelli et al., 2006).

Among anthropogenic contaminants, pesticides are widely detected in freshwater and estuarine ecosystems. These molecules are spread on terrestrial cultures and enter waterways from agricultural and urban run-off. Pesticides may have major ecological consequences (Ozretic and Krajnovic-Ozretic, 1992). The organophosphates (OPs) and carbamates (Cs) are modern synthetic insecticides and are potent neurotoxic molecules (Ashauer et al., 2006). They exert acute toxicity by blocking the breakdown of acetylcholine by the enzyme acetylcholinesterase (AChE: E.C.3.1.1.7) in vertebrate and invertebrate organisms (Fulton and Key., 2001). Acetylcholine is the primary neurotransmitter in the sensory and neuromuscular systems in most species. The activity of this system is vital to muscular function and represents a prime target on which OPs and Cs can exert a detrimental effect (Sarkar et al., 2006).

Monitoring AChE activity in wildlife populations has been proposed as a general method for detecting environmental contamination from OPs and Cs, particularly since many of these chemicals have relatively short half-lives in the aquatic environment and are not water soluble. The World Health Organization (Paris) recognizes AChE biomonitoring as a preventive measure against OP overexposure in nontarget species (Romani et al., 2005). Its use as a specific biomarker to assess the exposure of aquatic organisms to these compounds is 
widely applied in laboratory and field studies (Bocquené et al., 1997; Scaps et al., 1997; Galloway et al., 2002; Binelli et al., 2006).

In vertebrates two isoforms occur, acetylcholinesterase (AChE) which preferentially hydrolyses acetyl esters such as acetylcholine, and butyrylcholinestérases (BChE) which preferentially acts on butyrylcholine. The main function of AChE is the rapid hydrolysis of the neurotransmitter, whereas $\mathrm{BChE}$ has no known specific natural substrate, although it is able to hydrolyse acetylcholine (Fulton and Key, 2001; Valbonesi et al., 2003). Another isoform, propionylcholinesterase (PChE), has been characterized (Mora et al., 1999). Since the properties of ChE may differ between species, it is important to characterize the type of enzyme present in the species studied before its use as a biomarker (Kristoff et al., 2006).

Whilst ChEs have been extensively studied in vertebrates and insects, few data are available in molluscs (Mora et al., 1999). Molluscs, in particular bivalves, are often used as sentinel organisms: their world-wide distribution, their sedentary mode of life and their filterfeeding behaviour susceptible to induce pollutant bioaccumulation make them ideal species for the assessment of environmental pollution (Rittschof and McClellan-Green, 2005). Prosobranch snails including Potamopyrgus antipodarum (Hydrobiidae) and Valvata piscinalis (Valvatidae) are important members of aquatic habitats and possess a high ecological relevance for freshwater ecosystems (Mouthon and Charvet, 1999). They have proved to be sensitive test organisms in several studies (Oetken et al., 2005) and $P$. antipodarum has been recommended for toxicity tests by the Invertebrate testing group of OECD (Duft et al., 2007). Using these animals might facilitate the linking of laboratory data to field studies and field experiments could be undertaken on autochthonous or caged animals. The aim of this study was to characterize the ChE of mudsnails and to investigate the relevance of ChE activities as early warning tools of neurotoxic stress in two freshwater mudsnails. Activities in P. antipodarum and $V$. piscinalis were firstly characterized in vitro by 
94 using different substrates (acetylthiocholine (ASCh), propionylthiocholine (PSCh) and 95 butyrylthiocholine (BSCh)) and specific inhibitors (eserine for ChE, BW284c51 for AChE, 96 iso-OMPA for BChE). Secondly, in vivo effects of a model insecticide, chlorpyrifos, on ChE 97 activities were then studied in order to assess the value of $P$. antipodarum and $V$. piscinalis as 98 sentinel species of freshwater insecticide contamination.

99 

enzyme activity was initiated by the addition of ten $\mu \mathrm{L}$ of freshly prepared acetylthiocholine

\section{Material and Methods}

\section{Chemicals}

Acetylthiocholine iodide (ASCh), butyrylthiocholine iodide (BSCh), propionylthiocholine iodide (PSCh), 5,5-dithio-bis-2-nitrobenzoate (DTNB), eserine, BW284c51 (1,5-bis(4allydimethylammoniumphenyl)-pentan-3-one dibromide), iso-OMPA (tetra(monoisopropyl)pyrophosphor-tetra-mide) and chlorpyrifos were obtained from SigmaAldrich (Villefranche, France).

\section{Organisms}

$P$. antipodarum and $V$. piscinalis were obtained from the laboratory culture established in the laboratory (CEMAGREF, Lyon, France). Animals were reared under standard conditions in aerated glass aquariums $(17-20 \mathrm{~L})$, at a temperature of $22 \pm 1{ }^{\circ} \mathrm{C}$, and under a $16-8 \mathrm{~h}$ artificial light-dark photoperiod regime. For the cultures, animals were fed using Tetramin ${ }^{\circledR}$. For all experiments, adult snails of similar size $(4 \mathrm{~mm})$ were used.

\section{Cholinesterase activity}

The whole animals with shell were weighed and homogenized with an Ultra-Turrax T25 basic ${ }^{\circledR}$ at $24000 \mathrm{rpm}$ for 40 seconds in 1:10 (W:V) for $V$. piscinalis and 1:20 for $P$. antipodarum $0.1 \mathrm{M}$ phosphate buffer, $\mathrm{pH} 7.8$, plus $0,1 \%$ Triton X-100. Homogenates were centrifuged at $9,000 \times \mathrm{g}$ for $15 \mathrm{~min}$ at $4{ }^{\circ} \mathrm{C}$. Supernatants were used as the enzyme source.

The enzyme activity was measured following the Ellman method (1961). In a typical assay, $330 \mu \mathrm{L}$ of $0.1 \mathrm{M}$ phosphate buffer $\mathrm{pH} 7.8,20 \mu \mathrm{L}$ of $0.0076 \mathrm{M}$ the chromogenic agent DTNB and $20 \mu \mathrm{L}$ of sample were successively added in a 96 wells microtitre plate. Measurement of iodide solution in distilled water. Absorption of the 2-nitro-5-thiobenzoate anion, formed 
124 from the reaction, was then recorded at $405 \mathrm{~nm}$ every $60 \mathrm{~s}$ for 9 min at room temperature

125 using a TECAN ${ }^{\circledR}$ Safire $^{\circledR}$ spectrofluorimeter. Spontaneous substrate hydrolysis was assessed

126 using a blank without sample. Kinetic was calculated in the linear range. Each sample was

127 analyzed in triplicates. Total protein was determined according to the Lowry method (1951),

128 using bovine serum albumin as standard. Enzyme activity was expressed as nmol ASCh

129 hydrolysed $\mathrm{min}^{-1} \mathrm{mg}^{-1}$ of protein.

130

$131 \quad$ Substrate affinity

132 Substrate preference in supernatants obtained from control organisms was assessed using

133 ASCh, BSCh and PSCh as substrates. Fifteen animals sampled in our laboratory culture were

134 individually homogenized and supernatants were pooled and used as samples. The effects of

135 increased substrate concentration on supernatant ChE activity were determined with

136 concentrations of $\mathrm{ASCh}, \mathrm{BSCh}$ and $\mathrm{PSCh}$ ranging from 0.0625 to $8 \mathrm{mM}$. Three replicates of

137 each substrate were performed.

139 Specific inhibitors

140 Eserine, iso-OMPA and BW284c51 were used as specific inhibitors of ChEs, BChEs and

141 AChEs, respectively. Eserine and iso-OMPA were dissolved in ethanol and BW284c51 was

142 dissolved in distilled water. Ten animals were individually homogenized and supernatants

143 were pooled. Supernatants were then incubated 30 minutes at $20{ }^{\circ} \mathrm{C}$ with inhibitor or water or

144 ethanol for eserine and iso-OMPA (1\%). Final inhibitor concentrations ranged from 0.01 to

$145100 \mu \mathrm{M}$ for eserine and from 0.1 to $1000 \mu \mathrm{M}$ for iso-OMPA and BW284c51. Effects of

146 inhibitors on ChE activities were assessed using ASCh, BSCh and PSCh as substrates.

148 Chlorpyrifos exposure 
149 A seven days semi-static bioassay was performed, and the survival and the ChE activity of the

150 snails were followed in the course of the experiment. Snails were placed in glass beakers

151 filled with $300 \mathrm{~mL}$ of drilled ground water. Snails of both species were placed in the same

152 beakers, one day before the beginning of the contamination experiment for acclimatization.

153 Stock solutions of chlorpyrifos were prepared daily by dissolving chlorpyrifos in acetone used

154 as solvent, and diluted in an appropriate amount of drilled ground water, using serial dilution.

155 The concentration of acetone was kept at $0.05 \%$ in all pesticide solutions used. Solvent 156 (acetone) and solvent-free (drilled ground water) controls were included in the test design.

157 Water in beakers was renewed daily. For each concentration, five replicates with ten animals 158 of each species were carried out. One beaker of each nominal chlorpyrifos concentration was 159 added for chemical analyses. No food was added during the experiment. Tests were 160 performed as in rearing conditions.

161 Snails were exposed to three nominal chlorpyrifos concentrations $(0.14,2.86$ and $14.2 \mathrm{nM}$,

162 which correspond to $0.05,1$ and $\left.5 \mu \mathrm{g} . \mathrm{L}^{-1}\right)$. For each concentration, one individual of each 163 species were sampled on each of the five beaker per condition at $0,24,96$ and $168 \mathrm{~h}$ and 164 immediately frozen at $-80{ }^{\circ} \mathrm{C}$ until analysis.

Measurement of chlorpyrifos concentration in water

167 Samples for chlorpyrifos analyses were collected every day, 10 minutes and $24 \mathrm{~h}$ after the

168 water renewal in two beakers of each contamination levels $(0.14,2.86$ and $14.2 \mathrm{nM})$.

169 Chlorpyrifos was quantified after direct injection in LC-MS-MS. Chlorpyrifos ethyl standards

170 were purchased from Riedel De Haën (Sigma Aldrich, France). Standard stock solutions were

171 prepared by dissolving $5 \mathrm{mg}$ of accurately weighed reference standard in $50 \mathrm{~mL}$ acetone. The

172 stock solutions were diluted with ultrapure water (Milli-Q, Millipore) for LC-MS-MS analysis

173 standards. 
174 Water samples were collected in glass bottles and then filtered on $0.20 \mu \mathrm{m}$ polyester filters

175 (Chromafil PET 20/15 MS, Macherey-Nagel, Hoerdt, France). $990 \mu \mathrm{L}$ of filtered water was 176 added to $10 \mu \mathrm{L}$ of deutered diuron (D6) used as injection standard.

177 Liquid chromatography was performed on an Agilent Series 1100 HPLC system (Agilent

178 Technologies, Les Ulis, France). Chromatographic separation was achieved using a Synergi

179 Fusion-RP 80A analytical column (4 $\mu \mathrm{m}$ particle size, $2 \mathrm{~mm} \times 50 \mathrm{~mm}$ ) from Phenomenex (Le

180 Pecq, France), at a flow rate of $200 \mu \mathrm{L} \mathrm{min}{ }^{-1}$ with mobile phase consisting of acetonitrile and 181 water $(80 / 20, \mathrm{v} / \mathrm{v})$, both with $0.1 \% \mathrm{v} / \mathrm{v}$ formic acid. Injection volume was $100 \mu \mathrm{L}$. The HPLC

182 system was interfaced to a triple quadripole mass spectrometer (API 4000, Applied

183 Biosystems, Les Ulis, France). The following transitions $352 \rightarrow 200$ and $350 \rightarrow 198 \mathrm{~m} / \mathrm{z}$ were

184 used respectively for quantification and confirmation of chlorpyriphos ethyl. Quantification 185 was performed by internal calibration using diuron D6.

Data analysis

188 Results were expressed as means \pm standard error. Values were transformed $(\log \mathrm{X})$ to

189 achieve normality when necessary. Data were analysed using ANOVA on Statgraphics ${ }^{\circledR}$

190 Centurion version XV.II software. Significance was set at $p \leq 0.05$. In the case of rejection of

$191 \mathrm{H}_{0}$, an a posteriori LSD (Least Significant Difference) test was applied. When data showed a

192 concentration-dependant relationship, the median inhibitory concentration $\left(\mathrm{IC}_{50}\right)$ was

193 calculated by logistic curve-fitting procedure using REGTOX $^{\circledR}$

194 (http://eric.vindimian.9online.fr). The Michaelis-Menten constant $\left(K_{\mathrm{m}}\right)$ and the maximum

195 velocity of substrate hydrolysis $\left(V_{\max }\right)$ were calculated using GOSA $^{\circledR}$ software 196 (http://www.bio-log.biz). 
197

198

199

200

201

202

203

204

205

206

207

\section{$217 \quad$ Specific inhibitors}

218 Eserine decreased significantly ChE activities measured with the three substrates for the two

\section{Results}

In vitro experiments

\section{$\underline{\text { Substrate affinity }}$}

For $P$. antipodarum, measured esterase activities depended on the substrate. The reaction rate increased with increasing substrate concentration, with $\mathrm{ASCh}>\mathrm{PSCh}>\mathrm{BsCh}(\mathrm{p}<0.05)$ (Figure 1a). However, for the highest concentrations ( $>2 \mathrm{mM})$, no differences were measured between activities with ASCh and PSCh (Figure 1a). On the same way, increased ChE activity were measured for $V$. piscinalis, according to the substrate, with ASCh $>$ PSCh $>$ BsCh $(\mathrm{p}<0.05)$ (Figure 1b). No inhibitory effect was observed whatever the substrate used for both species. At the highest substrate concentration $(8 \mathrm{mM})$ enzymatic activities (expressed as nmol. $\mathrm{min}^{-1} \mathrm{mg}^{-1}$ protein) for P. antipodarum were $31.6 \pm 0.2$ for ASCh (100\%), $30.2 \pm 1.2$ for PSCh $(95.5 \%)$ and $2.7 \pm 0.3$ for BSCh $(8.5 \%)$. For $V$. piscinalis, enzymatic activities were $17.3 \pm 0.5$ for ASCh $(100 \%), 9.1 \pm 0.7$ for PSCh $(52.6 \%)$ and $3.9 \pm 0.3$ for BSCh (22.5\%). $4 \mathrm{mM}$ was defined as the optimal concentration for ASCh and PSCh for both species .

ChE activities followed the Michaelis-Menten kinetic when ASCh and PSCh were used as substrates for both species (Figure 1). Kinetics parameters $\left(K_{\mathrm{m}}, V_{\max }\right.$, and $\left.V_{\max } / K_{\mathrm{m}}\right)$ are reported in Table 1. $K_{\mathrm{m}}$ values were ten times higher for $V$. piscinalis than for $P$. antipodarum, whatever the substrate used.

species (Figure 2 a\&b). However, at $100 \mu \mathrm{M}$ of eserine, inhibition was lower for BSCh than for ASCh and PSCh for both snails. The inhibition profiles of ASCh and PSCh were similar for $P$. antipodarum and $V$. piscinalis. Nevertheless, whatever the substrate used, the $\mathrm{IC}_{50}$ 
values of eserine were lower for $P$. antipodarum $(0.034,5.29$ and $0.024 \mu \mathrm{M})$ than for $V$. piscinalis $(1.39,8.68$ and $1.40 \mu \mathrm{M})$ for ASCh, BSCh and $\mathrm{PSCh}$, respectively. Iso-OMPA only induced a significant decrease butyrylcholinesterase activity of $P$. antipodarum (Figure 2 c\&d). However, $50 \%$ of inhibition was not reached in our experiment).

BW284c51 significantly decreased the activities obtained for ASCh and PSCh for both gastropod species. For BSCh, the activity was significantly decreased only for $V$. piscinalis (Figure 2 e\&f). The inhibition profiles of $\mathrm{ASCh}$ and $\mathrm{PSCh}$ and the $\mathrm{IC}_{50}$ values were similar for $P$. antipodarum $(290.4$ and $387.1 \mu \mathrm{M})$ and $V$. piscinalis $(150.2$ and $262.2 \mu \mathrm{M})$ for ASCh and PSCh, respectively.

\section{In vivo experiments}

\section{Concentration of chlorpyrifos in water}

Chlorpyrifos concentrations in water were analyzed after 10 minutes and $24 \mathrm{~h}$ in the experimental conditions. Measured concentrations of chlorpyrifos for the three nominal concentrations $(0.14,2.86$ and $14.2 \mathrm{nM})$ were $0.28 \pm 0.02,2.65 \pm 0.2$ and $13.12 \pm 0.8 \mathrm{nM} 10$ minutes after water renewal, respectively, and $0.22 \pm 0.02,1.48 \pm 0.1,5.98 \pm 0.4 \mathrm{nM} 24 \mathrm{~h}$ after water renewal, respectively (data not shown). After $24 \mathrm{~h}$ of contamination, a decrease of concentration was observed: chlorpyrifos measured concentrations were $58.1,39.5$ and $27.2 \%$ of the concentrations measured at 10 minutes (data not shown).

\section{$\underline{\text { In vivo effects of chlorpyrifos on ChE activity }}$}

During the seven days of experiment, no mortality was reported for $P$. antipodarum, neither in controls, nor in contaminated beakers. A slight mortality was registered for $V$. piscinalis (5- 
$2466 \%$ of cumulative mortality), but this was not significantly different between controls and 247 contaminated animals (data not shown).

248 In vivo exposure to chlorpyrifos led to inhibition of ChE activity in P. antipodarum (Figure 249 3a). Decrease of activity was time and dose-dependent. After $24 \mathrm{~h}$ and $96 \mathrm{~h}$ of exposure, 250 activity was significantly decreased for $14.2 \mathrm{nM}$ compared to control. Values were 11.4 and $2514.9 \mathrm{nmol} \mathrm{ASCh} \cdot \mathrm{min}^{-1} \mathrm{mg}^{-1}$ protein, respectively, which represented an activity of 63.3 and $25231.5 \%$ of the control (100\%). At $168 \mathrm{~h}$, activity was significantly decreased for 2.86 and 14.2 $253 \mathrm{nM}$ compared to control. Values were 5.9 and $2.9 \mathrm{nmol}$ ASCh. $\mathrm{min}^{-1} \mathrm{mg}^{-1}$ protein, 254 respectively, which represented an activity of 40.5 and $20.2 \%$ of the control $(100 \%)$. $\mathrm{IC}_{50}$ 255 values of chlorpyrifos were $16.34,9.71$ and $3.15 \mathrm{nM}$ at 24,96 and $168 \mathrm{~h}$, respectively.

256 No significant inhibition occurred for $V$. piscinalis, however a slight significant increase 257 occurred for nominal concentration of $0.14 \mathrm{nM}$ after seven days of contamination $(\mathrm{p}<0.05$, 258 Figure 3b). 


\section{Discussion}

The level of ChE activity obtained for our species (31.6 for P. antipodarum and 17.3 nmol. $\mathrm{min}^{-1} \mathrm{mg}^{-1}$ protein for $V$. piscinalis) was quite similar to those reported in literature for several bivalve species (between 3 and $20 \mathrm{nmol} \cdot \mathrm{min}^{-1} \mathrm{mg}^{-1}$ protein) (Bocquené et al., 1997; Najimi et al., 1997; Mora et al., 1999; Valbonesi et al., 2003; Binelli et al., 2006). Literature reports AChE activities values of 20-45 nmol. $\mathrm{min}^{-1} \cdot \mathrm{mg}^{-1}$ protein for annelids (Eisena andrei (Caselli et al., 2006), Nereis diversicolor (Scaps and Borot, 2000)). However, an AChE activity of $320 \mathrm{nmol} \cdot \mathrm{min}^{-1} \cdot \mathrm{mg}^{-1}$ protein was reported in Lumbriculus variegatus (Kristoff et al., 2006). A few studies reported AChE level for other gastropods. The basal AChE activity of the bloodfluke planorb, Biomphalaria glabrata was $45 \mathrm{nmol} . \mathrm{min}^{-1} \mathrm{mg}^{-1}$ protein (Kristoff et al., 2006) and was $60 \mathrm{nmol} \cdot \mathrm{min}^{-1} \mathrm{mg}^{-1}$ protein for the murex, Hexaplex trunculus (Romeo et al., 2006).

Vertebrate cholinesterases have been classified into two groups, acetyl ChE and butyryl ChE, depending on substrate hydrolysis and sensitivity to inhibitors. AChE hydrolyses ASCh much faster than other choline esters, like PSCh, and is inactive on BSCh, whereas $\mathrm{BChE}$ hydrolyses both $\mathrm{BSCh}$ and $\mathrm{ASCh}$ at an appreciable rate (Valbonesi et al., 2003). Several studies show that situation of invertebrate cholinesterases is more complex. ASCh has been reported as the preferential substrate for most bivalves including oysters (Bocquené et al., 1997; Valbonesi et al., 2003), marine and freshwater mussels (Mora et al., 1999; Romani et al., 2005; Binelli et al., 2006), as well as for E. andrei (Caselli et al., 2006), B. glabrata (Kristoff et al., 2006), and the common shredder, Gammarus pulex (Xuereb et al., 2007).

Both species of gastropods studied here showed different affinities toward the three substrates used (ASCh, PSCh and BSCh). At high concentrations of substrates, $P$. antipodarum cholinesterase presented the same affinity for ASCh and PSCh. $V$. piscinalis 
presented a higher affinity for ASCh. However, the enzymatic activity level was lower for $V$. piscinalis. In our study, gastropods revealed a low BSCh hydrolysis.

Comparative analysis of the $\mathrm{Km}$ values in $P$. antipodarum indicated that $\mathrm{ChE}$ affinity for ASCh and PSCh were in the same range of that reported for E. andrei $(0.18$ and $0.14 \mathrm{mM}$ for ASCh and PSCh, respectively) (Caselli et al., 2006) and the Pacific oyster, Crassostrea gigas (0.124 mM for PSCh) (Bocquené et al., 1997), while $V$. piscinalis showed higher values, closer to those reported in the blue mussel, Mytilus edulis (1.3 $\mathrm{mM}$ for ASCh) (Galloway et al., 2002). Moreover, these values appeared one order of magnitude higher than that generally reported for bivalves: $50-93 \mu \mathrm{M}$ for Ostrea edulis, Mytilus galloprovincialis, Crassostrea. gigas (ASCh), Corbicula fluminea (PSCh), Perna perna (Bocquené et al., 1997; Najimi et al., 1997; Mora et al., 1999; Valbonesi et al., 2003). High Km values represent lower ChE affinity by substrate. Therefore, ChE activities of $V$. piscinalis presented lower affinity to substrates than $P$. antipodarum ones.

$V \max$ values were similar for both species. For P. antipodarum, the ASCh ratio $V \max / K m$ was in the same range that those reported in M. galloprovincialis $\left(0.24 \mathrm{~mL} \cdot \mathrm{min}^{-1} \cdot \mathrm{mg}^{-1}\right.$ protein) (Valbonesi et al., 2003) and E. andrei $\left(0.25 \mathrm{~mL} \cdot \mathrm{min}^{-1} \cdot \mathrm{mg}^{-1}\right.$ protein) (Caselli et al., 2006). ASCh $V \max / \mathrm{Km}$ ratio for $V$. piscinalis was closer to O. edulis one $\left(5.1 .10^{-2} \mathrm{~mL} . \mathrm{min}^{-}\right.$ ${ }^{1} . \mathrm{mg}^{-1}$ protein) (Valbonesi et al., 2003). These results indicated that $V$. piscinalis enzyme has a lower efficiency of hydrolysis than $P$. antipodarum, in agreement with the lower activity observed and with the lower substrate affinity, as discussed before.

Enzymatic activity observed with BSCh was inhibited for both species by eserine, a cholinesterase inhibitor. Enzymatic activities measured using ASCh and PSCh were almost totally inhibited by eserine in both species. Iso-OMPA, a specific inhibitor of $\mathrm{BChE}$ in vertebrates (Bocquené et al., 1997), did not modified this activity in $V$. piscinalis. However, a 
significant inhibition occurred in $P$. antipodarum. An important decrease was observed in both species with BW284c51, specific inhibitor of AChEs in vertebrates (Caselli et al., 2006).

The whole results suggest that $V$. piscinalis possesses a single ChE isoform, which presents

311 all the properties of a vertebrate AChE: high preference for ASCh and low for BSCh; high

312 sensitivity to eserine and BW284c51, but not to iso-OMPA. On the contrary, more complex

313 isoforms of $\mathrm{ChE}$ seem to coexist in P. antipodarum, one major isoform presenting properties

314 intermediate between an $\mathrm{AChE}$ and a PChE, and another minor isoform presenting properties of a BChE.

$\mathrm{IC}_{50}$ reported for eserine in $P$. antipodarum were in the same range than the values reported for other invertebrates $(0.01,0.01,0.14,0.020$ and $0.014 \mu \mathrm{M}$ for B. glabrata, $L$. variegatus, O. edulis, M. galloprovincialis and E. andrei, respectively) (Valbonesi et al., 2003; Caselli et al., 2006; Kristoff et al., 2006). However, values for $V$. piscinalis were higher. These results suggest that $V$. piscinalis ChEs are less sensitive that in $P$. antipodarum. In our experiments, we measured effects of chlorpyrifos on P. antipodarum and $V$. piscinalis. Chlorpyrifos is a widely used organophosphate insecticide and is the active ingredient in a number of commonly used household and agricultural insecticide formulations (Fulton and Key, 2001). It is volatile and concentration decreases rapidly in water in constant exposure conditions. For these reasons, we performed the laboratory experiment using semistatic conditions. Nevertheless, an important decrease of chlorpyrifos level was measured 328 after $24 \mathrm{~h}$. A similar $50 \%$ loss was reported in a contamination experiment of G. pulex to 0.3 $329 \mathrm{nM}$ of chlorpyrifos: concentration reached $0.17 \mathrm{nM}$ after $24 \mathrm{~h}$ of exposition (Ashauer et al., 330 2006).

331 Chlorpyrifos was tested in this study at concentrations ranging from 0.14 to $14.2 \mathrm{nM}(0.05-5$ $\left.332 \mu \mathrm{g} \cdot \mathrm{L}^{-1}\right)$. Measured concentrations of chlorpyrifos in surface waters often fall at concentrations 
333 below the nM level (USEPA, 2002). However, studies showed that chlorpyrifos 334 concentrations in small streams and wetlands adjacent to agricultural fields could range from 3350.2 to $2 \mu \mathrm{M}$ (Mazanti et al., 2003). Moreover, the relatively short-half life of chlorpyrifos in 336 water may result in underestimate levels of exposure (Mazanti et al., 2003).

337 We demonstrated the dose-response and time-dependant effects of chlorpyrifos on $P$. 338 antipodarum: for $14.2 \mathrm{nM}$, inhibition was $40 \%$ of the control after $24 \mathrm{~h}$ of contact and 339 increased to $80 \%$ of the control after $168 \mathrm{~h}$ of contact, without significant mortality. However, 340 an increase was shown on $V$. piscinalis. Chlorpyrifos have already been shown as a powerful 341 AChE inhibitor in invertebrates. Chlorpyrifos decreased AChE activity after $96 \mathrm{~h}$ of contact in 342 D. polymorpha $(0.03 \mathrm{nM})$ (Binelli et al., 2006) and in C. fluminea (80\% inhibition at 1.4 and $3432.8 \mu \mathrm{M})($ Cooper and Bidwell, 2006). Chlorpyrifos also decreased in vitro AChE activity in 344 M. edulis (Galloway et al., 2002) and in in vivo exposures in the midge, Chironomius riparius 345 (Callaghan et al., 2001) and in rat brain (Hancock et al., 2007), which agrees with our results. 346 On the contrary, this OP increased AChE activity in S. inaequivalvis after 15 days of exposure 347 to $0.3 \mathrm{nM}$ (Romani et al., 2005), which comforts our results on $V$. piscinalis; however, the 348 biological explanation remains unknown. $\mathrm{IC}_{50}$ of chlorpyrifos for $\mathrm{AChE}$ was $9.71 \mathrm{nM}$ in $P$. 349 antipodarum at $96 \mathrm{~h}$, which was ten times higher that for G. pulex in the same experimental 350 conditions (Xuereb et al., 2007).

High resistance of $V$. piscinalis to eserine in vitro and to chlorpyrifos in vivo may be related to the lower $\mathrm{ChE}$ affinity to the substrate. On the contrary, high substrate specificity and high sensitivity to eserine in vitro and chlorpyrifos in vivo would suggest that $P$. antipodarum ChEs could be very sensitive to anticholinesterase agents.

In our study, we showed that inhibition of AChE happened for P. antipodarum without any mortality. The relationship between AChE inhibition and mortality in 
358 invertebrates is generally less well established than in vertebrates. No mortality was observed 359 after an environmental contamination with azinphos-methyl in B. glabrata et L. variegatus 360 (Kristoff et al., 2006), even though inhibition of AChE reached between 35 and 99\% of 361 control. However, a high mortality was observed in $N$. diversicolor contaminated with 362 parathion and malathion when 55\% of AChE inhibition occurred (Scaps et al., 1997). A high

363 mortality and $70 \%$ of AChE inhibition also occurred in G. pulex exposed to chlorpyrifos 364 (Xuereb et al., 2007). More research is needed to clarify the relationships between OP exposure, AChE inhibition and mortality. P. antipodarum AChE could be an useful biomarker of pesticide contamination as its

367 inhibition occurred at low concentration without mortality. Therefore, $P$. antipodarum could

368 be used in field contamination assessment. However, ChE activities may be differentially 369 modulated depending on the pollutant tested (Ozretic and Krajnovic-Ozretic, 1992). To better 370 assess the interest of $P$. antipodarum as field sentinel species, we need to confirm its 371 sensitivity to several anti-cholinesterase compounds and in different exposure conditions. 372 Moreover, as pesticide contamination in the field is a discontinuous phenomenon, it will be 373 necessary to test recovery of AChE activity after a contamination and to assess the effects of 374 successive contamination exposure.

\section{Conclusion}

377 The aim of our work was to characterize $P$. antipodarum and $V$. piscinalis ChEs. Our results 378 show that $P$. antipodarum possesses several isoforms of ChEs, one undifferentiated between 379 an $\mathrm{AChE}$ and a $\mathrm{PChE}$, and another one which could be assimilated as a BChE. $V$. piscinalis 380 seems to possess only one isoform close to the vertebrate AChE. Our results also illustrate the 381 relative insensitivity of $\mathrm{ChE}$ activity following $V$. piscinalis exposure to environmental 
382 concentrations of chlorpyrifos. On the contrary, the present study gives valuable indications

383 for selecting $P$. antipodarum in biomonitoring programs.

384 Laboratory studies generally do not take into account natural stressors, including fluctuations

385 in biotic and abiotic factors, which could have effects on AChE activity (Bocquené et al., 386 1997). Some complementary experiments are needed in order to identify the factors inducing

387 ChE variability (age, season) in order to make the difference between effects due to chemical 388 exposure and the natural variability.

\section{Acknowledgments}

391 R. Mons and H. Queau are acknowledged for their technical assistance during chlorpyrifos

392 contamination. C. Guillemain is acknowledged for the chlorpyrifos analyses. 


\section{References}

394 Ashauer, R., Boxall, A., Brown, C., 2006. Uptake and elimination of chlorpyrifos and 395 pentachlorophenol into the freshwater amphipod Gammarus pulex. Arch. Environ. Con. Tox. $39651,542-548$.

397 Binelli, A., Ricciardi, F., Riva, C., Provini, A., 2006. New evidences for old biomarkers: 398 Effects of several xenobiotics on EROD and AChE activities in Zebra mussel (Dreissena 399 polymorpha). Chemosphere 62, 510-519.

400 Bocquené, G., Roig, A., Fournier, D., 1997. Cholinesterases from the common oyster 401 (Crassostrea gigas). Evidence for the presence of a soluble acetylcholinesterase insensitive to 402 organophosphate and carbamate inhibitors. FEBS Lett. 407, 261-266.

403 Callaghan, A., Hirthe, G., Fisher, T., Crane, M., 2001. Effect of short-term exposure to 404 chlorpyrifos on developmental parameters and biochemical biomarkers in Chironomus 405 riparius Meigen. Ecotox. Environ. Safe. 50, 19-24.

406 Caselli, F., Gastaldi, L., Gambi, N., Fabbri, E., 2006. In vitro characterization of 407 cholinesterases in the earthworm Eisenia andrei. Comp. Biochem. Phys. C 143, 416-421.

408 Cooper, N.L., Bidwell, J.R., 2006. Cholinesterase inhibition and impacts on behavior of the 409 Asian clam, Corbicula fluminea, after exposure to an organophosphate insecticide. Aquat. 410 Toxicol. 76, 258-267.

411 Duft, M., Schmitt, C., Bachmann, J., Brandelik, C., Schulte-Oehlmann, U., Oehlmann, J., 412 2007. Prosobranch snails as test organisms for the assessment of endocrine active chemicals-413 an overview and a guideline proposal for a reproduction test with the freshwater mudsnail 414 Potamopyrgus antipodarum. Ecotoxicology 16, 169-182.

415 Ellman, G.L., Courtney, K.D., Andres, V., Jr., Feather-Stone, R.M., 1961. A new and rapid 416 colorimetric determination of acetylcholinesterase activity. Biochem. Pharmacol. 7, 88-95. 
417 Fulton, M.H., Key, P.B., 2001. Acetylcholinesterase inhibition in estuarine fish and 418 invertebrates as an indicator of organophosphorus insecticide exposure and effects. Environ. 419 Toxicol. Chem. 20, 37-45.

420 Galloway, T.S., Millward, N., Browne, M.A., Depledge, M.H., 2002. Rapid assessment of 421 organophosphorous/carbamate exposure in the bivalve mollusc Mytilus edulis using combined 422 esterase activities as biomarkers. Aquat. Toxicol. 61, 169-180.

423 Hancock, S., Ehrich, M., Hinckley, J., Pung, T., Jortner, B.S., 2007. The effect of stress on the 424 acute neurotoxicity of the organophosphate insecticide chlorpyrifos. Toxicol. Appl. Pharm. 219, 136-141.

426 Kristoff, G., Guerrero, N.V., de D'Angelo, A.M.P., Cochon, A.C., 2006. Inhibition of 427 cholinesterase activity by azinphos-methyl in two freshwater invertebrates: Biomphalaria 428 glabrata and Lumbriculus variegatus. Toxicology 222, 185-194.

429 Lowry, O.H., Rosebrough, N.J., Farr, A.L., Randall, R.J., 1951. Protein measurement with the 430 Folin phenol reagent. J. Biol. Chem. 193, 265-275.

431 Mazanti, L., Rice, C., Bialek, K., Sparling, D., Stevenson, C., Johnson, W.E., Kangas, P., 432 Rheinstein, J., 2003. Aqueous-phase disappearance of atrazine, metolachlor, and chlorpyrifos 433 in laboratory aquaria and outdoor macrocosms. Arch. Environ. Con. Tox. 44, 67-76.

434 Mora, P., Michel, X., Narbonne, J.-F., 1999. Cholinesterase activity as potential biomarker in 435 two bivalves. Environ. Toxicol. Phar. 7, 253-260.

436 Mouthon, J., Charvet, S., 1999. Compared sensitivity of species, genera and families of 437 Molluscs to biodegradable pollution. Ann. Limnol-Int. J. Lim. 35, 31-39.

438 Najimi, S., Bouhaimi, A., Daubeze, M., Zekhnini, A., Pellerin, J., Narbonne, J.F., Moukrim, 439 A., 1997. Use of acetylcholinesterase in Perna perna and Mytilus galloprovincialis as a 440 biomarker of pollution in Agadir marine bay (South of Morocco). B. Environ. Contam. Tox. $44158,901-908$. 
442 Oetken, M., Nentwig, G., Loffler, D., Ternes, T., Oehlmann, J., 2005. Effects of 443 pharmaceuticals on aquatic invertebrates. Part I. The antiepileptic drug carbamazepine. Arch. 444 Environ. Con. Tox. 49, 353-361.

445 Ozretic, B., Krajnovic-Ozretic, M., 1992. Esterase heterogeneity in mussel Mytilus 446 galloprovincialis: effects of organophosphate and carbamate pesticides in vitro. Comp. 447 Biochem. Phys. C 103, 221-225.

448 Rittschof, D., McClellan-Green, P., 2005. Molluscs as multidisciplinary models in 449 environment toxicology. Mar. Pollut. Bull. 50, 369-373.

450 Romani, R., Isani, G., De Santis, A., Giovannini, E., Rosi, G., 2005. Effects of chlorpyrifos 451 on the catalytic efficiency and expression level of acetylcholinesterases in the bivalve mollusk 452 Scapharca inaequivalvis. Environ. Toxicol .Chem. 24, 2879-2886.

453 Romeo, M., Gharbi-Bouraoui, S., Gnassia-Barelli, M., Dellali, M., Aissa, P., 2006. Responses 454 of Hexaplex (Murex) trunculus to selected pollutants. Sci. Total Environ. 359, 135-144.

455 Sarkar, A., Ray, D., Shrivastava, A.N., Sarker, S., 2006. Molecular biomarkers: Their 456 significance and application in marine pollution monitoring. Ecotoxicology 15, 333-340.

457 Scaps, P., Demuynck, S., Descamps, M., Dhainaut, A., 1997. Effects of organophosphate and 458 carbamate pesticides on acetylcholinesterase and choline acetyltransferase activities of the 459 polychaete Nereis diversicolor. Arch. Environ. Con. Tox. 33, 203-208.

460 Scaps, P., Borot, O., 2000. Acetylcholinesterase activity of the polychaete Nereis diversicolor: 461 effects of temperature and salinity. Comp. Biochem. Phys. C 125, 377-383.

462 U.S.E.P.A., 2002. Interim registration eligibility decision for chlorpyrifos. URL: 463 http://www.epa.gov/REDs/chlorpyrifos ired.pdf. Final/Technical Report, U.S. Environmental 464 Protection Agency, Washington D.C. 
465 Valbonesi, P., Sartor, G., Fabbri, E., 2003. Characterization of cholinesterase activity in three 466 bivalves inhabiting the North Adriatic sea and their possible use as sentinel organisms for 467 biosurveillance programmes. Sci. Total Environ. 312, 79-88.

468 van der Oost, R., Beyer, J., Vermeulen, N.P.E., 2003. Fish bioaccumulation and biomarkers in 469 environmental risk assessment: a review. Environ. Toxicol. Phar. 13, 57-149.

470 Xuereb, B., Noury, P., Felten, V., Garric, J., Geffard, O., 2007. Cholinesterase activity in 471 Gammarus pulex (Crustacea, Amphipoda): characterization and effects of chlorpyrifos. 472 Toxicology 236, 178-189.

473

474

475

476 


\section{Figure captions}

477 Figure 1: substrate affinity of $P$. antipodarum (a) and $V$. piscinalis (b) ChEs measured at 478 increasing concentrations of ASCh, PSCh and BSCh. Values are means of three replicates. 479 Standard error is presented. a, b, and c represent significant differences between substrates at $480 \mathrm{p}<0.05(\mathrm{a}>\mathrm{b}>\mathrm{c})$.

482 Figure 2: effects of eserine (a \& b), iso-OMPA (c \& d) and BW284c51 (e \& f) on ChE 483 activity in $P$. antipodarum (a, c \& e) and $V$. piscinalis (b, d \& f). Standard error is presented. $484 *$ : $<<0.05 ; * * *: \mathrm{p}<0.001$.

486 Figure 3: inhibition percentages of $\mathrm{ChE}$ activities for $P$. antipodarum (a) and $V$. piscinalis (b) 487 during in vivo contamination with chlorpyrifos. Values are means of five replicates. Standard 488 error is presented. ***: $\mathrm{p}<0.001$

491 Table 1. Michaelis-Menten constant $\left(K_{\mathrm{m}}\right)$ and maximum rate of substrate hydrolysis $\left(V_{\max }\right)$ of 492 ChEs of $P$. antipodarum and $V$. piscinalis. Results are expressed as the mean $\pm \mathrm{SE}$ of three 493 replicates. 